The Catholic University of America, Columbus School of Law

CUA Law Scholarship Repository

1994

\title{
Images of Women in U.S. Immigration Policy: The Paradox of Domestic Violence
}

Stacy Brustin

The Catholic University of America, Columbus School of Law

Follow this and additional works at: https://scholarship.law.edu/scholar

Part of the Immigration Law Commons, and the Law and Gender Commons

\section{Recommended Citation}

Stacy L. Brustin, Images of Women in U.S. Immigration Policy: The Paradox of Domestic Violence, 88 PROC. AM. SOC'Y IN'TL L. 454 (1994).

This Article is brought to you for free and open access by the Faculty Scholarship at CUA Law Scholarship Repository. It has been accepted for inclusion in Scholarly Articles and Other Contributions by an authorized administrator of CUA Law Scholarship Repository. For more information, please contact edinger@law.edu. 
part of both refugee-sending and refugee-receiving states. Again using Haiti as an example, General Raoul Cedras recently made public statements charging that U.S. intervention in Haitian internal affairs violates Haitian sovereignty, even though his own government is illegitimate and has been committing large-scale abuses against its own people. Nevertheless, the U.S. Government has been surprisingly timid about disputing this bogus sovereignty claim, in part because it has had to deny the reality of the ongoing human rights abuses in order to justify keeping out the Haitian aliens, whom it has come to view as "bad." Consequently, the U.S. Government is now asserting its own false sovereignty claim as its justification for intercepting and returning the fleeing Haitians.

In a parallel way, the Chinese Government is invoking both sovereignty and cultural relativism - the two last bastions of human rights abusers-to claim "overall significant progress" in human rights as a reason to maintain most-favored-nation status in its trading relations with the United States after July 1994. Our fear should be that the U.S. Government will actually accept these claims, motivated not by its belief that they are true, but by its desire to prevent the inevitable outflows of "bad aliens" from the largest country in the world, should it continue to crack down on Chinese human rights abusers.

The crucial point is that the international human rights movement worked a fundamental transformation of sovereignty, piercing the veil of sovereignty in the face of human rights violations by a government against its own people. Whether in Nazi Germany, Haiti or China, it would doubly undo that historical transformation of sovereignty, if our own government-driven by a fear of bad aliens-chose not only to defer to false claims of sovereignty by the human rights violators, but also to invoke specious claims of Haiti's sovereignty as a reason to aid and abet human rights violations, by returning human rights victims to their persecutors.

\section{Images of Women in U.S. Immigration Policy-The Paradox of Domestic VIOLENCE}

\section{By Stacy Brustin*}

In February 1991, immigrant women from various parts of Central and South America formed the Hermanas Unidas Project (Sisters United) at Ayuda Inc. Ayuda Inc. is a legal services center in Washington, D.C. The group, comprised largely of survivors of domestic violence, provides moral support and leadership to women in the District of Columbia. During the past three years, these women have changed the landscape of their community in significant ways, including educating immigrants and nonimmigrants about the realities of domestic violence. Yet these strong, independent, activist women are not the immigrants portrayed in immigration policy.

Women, as a group, are relatively invisible in immigration policy and there is little written on their migration patterns and life experiences. Immigration policies that profoundly impact women, such as spouse-based immigration laws, foster images of immigrant women as dependents of men, perpetrators of fraud and public burdens. The anti-immigrant furor in this country reinforces and perpetuates the negative images.

Immigrant rights advocates have had to operate against restrictive immigration policy and virulently anti-immigrant public opinion to develop strategies that will help immigrant women acquire status. Recently, experience with efforts to include

\footnotetext{
* Columbus School of Law, The Catholic University of America.
} 
protections for battered immigrant women in the Immigration and Nationality Act of $1990,{ }^{1}$ and the Violence Against Women Act, ${ }^{2}$ demonstrate ways in which the identity of women as immigrants is downplayed and their plight as "helpless" victims of spousal abuse is emphasized in order to enact needed immigration reform. This strategy of obscuring the identity of immigrant women may be a politically necessary way of acquiring legal status for women who need and deserve such status. The policy which results, however, fosters an image of the "good female alien" rooted in notions of passivity and helplessness.

Immigration policy is and always has been integrally tied to our country's economic and foreign policy. ${ }^{3}$ The definition of aliens considered worthy of legal status has varied depending upon domestic labor needs and perceived national political interests. Historically, males were allowed to immigrate as workers depending upon the needs of industries in the United States, but they rarely were allowed to bring wives and children. Women who began immigrating in larger numbers to the United States in the early 1900 s did so to join husbands who were already here. ${ }^{4}$

For the past hundred years, the image of women portrayed in immigration policy has been one of dependence on men. The law has treated women as property of men and left the decision to legalize women's status to the discretion of their husbands. ${ }^{5}$ In the 1920 s, for example, restrictive immigration laws gave male citizens and male permanent residents control over the immigrant status of their wives, for these women could not acquire status unless their husbands filed a petition on their behalf. This immigration policy tracked the traditional family law doctrine of coverture. A woman lacked legal status independent of her husband. ${ }^{6}$

Spouse-based immigration, in which an alien female spouse becomes a legal resident only if her citizen or resident husband petitions for her, has continued to the present under the Immigration and Nationality Act (INA). ${ }^{7}$ In the 1986 Immigration Marriage Fraud Amendments ${ }^{8}$ to the INA, once a citizen or legal resident filed a petition on behalf of his or her spouse, a conditional residency period was established in which a person married for less than two years would have to complete a two-year waiting period until she could acquire permanent residency. In order for the undocumented spouse to remove the conditional residency status, the couple would have to file a joint petition and submit to an interview. The change in law applied to both males and females, but had a particularly dramatic effect on women, who comprise the majority of immigrants acquiring status through a spouse. ${ }^{9}$

As a result of the 1986 amendments, immigrant women in abusive relationships were placed in a terrible bind. They were dependent upon their husbands to file

\footnotetext{
${ }^{1}$ Immigration Act of 1990, Pub. L. No. 101-649, 104 Stat. 4978 (1990), § 216, 8 U.S.C. $\$ 1186$ (c)(4) (1990).

2 Violent Crime Control and Law Enforcement Act of 1994, Pub. L. No. 103-322, § 40701, 40702, 40703108 Stat. 179, 1953-55 (1994).

${ }^{3}$ William R. Tamayo, The Evolution of United States Immigration Policy, in DOMESTIC VIOLENCE in Immigrant and Refugee Communities: Asserting the Rights of Battered Women IV-1 (1991).

${ }^{4}$ Chris Hogeland, Immigrant Women in United States History, Id. at V-1 (1991).

${ }^{5}$ Calvo, Spouse-Based Immigration Laws: The Legacies of Coverture, 28 SAN DiEgo L. REv. 593 , 600-01 (1991).

${ }^{6} I d$., at 595.

${ }^{7}$ Immigration and Nationality Act of 1952, Pub. L. No. 414, 66 Stat. 166 (1952).

8 U.S.C. $\$ 1186(a)(1988)$.

${ }^{9}$ Hogeland, supra note 4, at V-18-19, citing Houstoun, Kramer, \& Mackin Barrett, Female Predominance in Immigration Since 1930: A First Look, 4 INT'L Migration REV. 913 (1984).
} 
an initial petition and they remained dependent upon him to file a joint petition and submit to an interview at the end of the conditional period (if they had been married less than two years). The husband could abuse with abandon knowing that the hope of legal status placed his wife at his mercy if she wanted to remain in the country.

The 1986 reforms ostensibly target "manipulative" males and females who come to the United States to improve their economic condition and would do anything, the theory goes, including entering into fraudulent marriages, to obtain legal status in the United States. Despite the fact that the studies the INS used to determine the frequency of fraudulent marriages were subsequently exposed as highly flawed and suspect, ${ }^{10}$ the perception persisted. The amendments were designed to impede these "bad aliens" and in the process perpetuated an image of women as subordinate and exacerbated the danger for battered women.

In response to this problem, the Immigration Act of 1990 incorporated a waiver to benefit battered spouses and children. ${ }^{11}$ Under the new provision, a conditional resident spouse is required to show that she entered the marriage in good faith, but that the citizen or permanent resident spouse physically or psychologically abused her and/or her children. If she can demonstrate abuse, then she may obtain permanent residency without the joint petition and joint interview. Although the law is written in a gender-neutral fashion, the change primarily impacts women because the overwhelming majority of victims of domestic violence are women..$^{12}$

The regulations implementing the 1990 law impose costly hurdles for proving physical and psychological abuse. In order to support a waiver, a battered spouse must present evidence of "reports and affidavits from police, medical personnel, psychologists, school officials and social service agencies." 13 Many battered immigrant women cannot afford to seek the services of psychologists to document their psychological abuse. Further, immigrant women are often fearful of seeking help from public agencies for fear of deportation or retribution by their husbands or families. ${ }^{14}$ Many battered women thus cannot qualify for the waiver.

The 1990 waiver maintains spouse-based immigration and thereby the image of female immigrants as subordinate to and dependent upon men. In addition, the image of aliens as deceptive and likely to commit fraud persists, for a person may not avail him- or herself of the battered-spouse waiver unless she or he demonstrates that the marriage was entered into in good faith and presents documentary corroboration of the abuse. Nevertheless, the reform carves out a sphere of independence for women, available only to those who can demonstrate that they are "victims." The policy and public debate centers around an image of immigrant women as deserving of legalization because they are frightened, helpless victims.

The waiver provisions of the 1990 Immigration Act are intended to aid battered women who have acquired conditional status. Two large groups of women, however, remain hostage to abusive husbands: women whose husbands have not filed an application for legalization and women whose husbands have filed but who are not yet eligible for legal permanent residency status and therefore not entitled to

${ }^{10}$ Calvo, supra note 3 , at 607 .

118 C.F.R. \& 216.5(3) (1992).

12 U.S. Commission on Civil Rights, Under the Rule of Thumb: Battered Women AND the AdMinistration OF JUSTICE (1982).

${ }^{13}$ Supra note 11.

${ }^{14}$ See Kimberle Crenshaw, Mapping the Margins: Intersectionality, Identity Politics, and Violence Against Women of Color, in AFTER IDENTTTY: A READER IN LAW \& CULTURE 332, 334-37 (Dan Danielson \& Karen Engle eds, 1994). 
apply for a battered spouse waiver ${ }^{15}$ In an effort to address these shortcomings, immigration and domestic violence advocates proposed that an immigration reform section be added to the Violence Against Women Act which, if enacted, would enable immigrants trapped in abusive marriages to "self-petition" rather than remain dependent on their abusive spouse to file. ${ }^{16}$ The bill passed in the House 421-0 in November 1993. The Senate passed a version of the act which did not include the provision. The issue will go before a U.S. House-Senate Conference Committee and hopefully the self-petitioning provision will become law. ${ }^{17}$

Those who lobbied for this legislation consciously adopted a strategy focusing on women as victims of domestic violence and downplaying their identity as immigrants. ${ }^{18}$ The decision to introduce this legislation through the Violence Against Women Act rather than as an amendment to existing immigration law was a calculated one. Advocates were keenly aware that victims of spousal violence are generally viewed with sympathy (at least publicly), whereas female immigrants, particularly women of color from developing countries whose governments are not seen as a threat to U.S. security, are viewed as public burdens. ${ }^{19}$ This is not an attempt to criticize these tireless advocates, nor a suggestion that immigrant women should be excluded from legislation aimed at fighting violence against all women. However, it is problematic that immigration policy fosters the notion of women as deserving of status when they are perceived of as weak, passive victims. There is no public recognition of the strength of immigrant women nor of the significant contributions that they make on a daily basis to our society.

The current backlash against immigrants portrays female aliens, both documented and undocumented, as lazy individuals who feed off the U.S. public welfare system. The reality, however, is that immigrant women provide needed agricultural labor, form the backbone of garment industries and clean homes and care for children in thousands of households throughout the country. ${ }^{20}$ Immigrants pay more in taxes than they receive in social services ${ }^{21}$ and undocumented immigrants are particularly fearful of using services and public benefits. ${ }^{22}$ Immigrant women who have journeyed great distances and experienced numerous hardships at home and in the United States are women of strength, vision and courage.

The women who coordinate the Hermanas Unidas Project, for example, have immigrated to this country from Central and South America. They come from a variety of educational and economic backgrounds, but once in this country have worked primarily as domestic workers, short order cooks and hotel maids. Most of the women are singlehandedly raising their children. A small percentage of the members receive public benefits for only a short time. Whether undocumented

\footnotetext{
${ }^{15}$ Untold Stories: Cases Documenting Abuse by U.S. Citizens and Lawful Residents on Immigrant Spouses Prepared by a Coalition of Organizations Advocating on Behalf of Immigrants and Battered Women. Compiled by the Family Violence Prevention Fund, San Francisco, California (1993).

${ }^{16}$ Supra note 4.

${ }^{17}$ Bill Would Protect Immigrants "Trapped"' in Abusive Marriages, Phoentx Gazette, Jan. 7, 1994, at B9; A Bill to Aid Battered Immigrant Women, N.Y. TnMEs, Dec. 14, 1993, at 24; Caught in $a$ Vicious, Bitter Trap, L. A. Times, Oct. 8, 1993, at 1.

${ }^{18}$ Discussions with Leslye Orloff, Director of Program Development, Ayuda Inc., Washington, DC, one of the chief proponents of the self-petitioning provisions.

${ }^{19}$ Supra note 14 , at 6,7 .

${ }^{20}$ National Council of La Raza, Advocate's Quick Reference Guide to Immigration Research 1993; Hogeland, supra note 4, at V-12-V-17.

${ }^{21}$ Frank Sharry, Myths, Realities and Solutions, SpECTRUM 20, 24 (Winter 1994).

${ }^{22}$ National Council of La Raza, supra note 18, at 6.
} 